\section{DIGITAL COMMONS \\ @ UNIVERSITY OF SOUTH FLORIDA}

\section{ABO: Interactive Journal for Women in the Arts, 1640-1830}

Volume 2

Issue 1 Volume 2.1 (Spring 2012): Open Access

Article 5

2012

\title{
'A Strange Sympathy': The Rhetoric of Emotion in The History of the Nun; or, The Fair Vow-Breaker
}

\author{
Elizabeth J. Mathews \\ University of California, Irvine, elizabethjmathews@gmail.com
}

Follow this and additional works at: https://digitalcommons.usf.edu/abo

Part of the Dramatic Literature, Criticism and Theory Commons, Educational Methods Commons, Feminist, Gender, and Sexuality Studies Commons, and the Literature in English, British Isles Commons

\section{Recommended Citation}

Mathews, Elizabeth J. (2012) "'A Strange Sympathy': The Rhetoric of Emotion in The History of the Nun; or, The Fair Vow-Breaker," ABO: Interactive Journal for Women in the Arts, 1640-1830: Vol.2: Iss.1, Article 5. http://dx.doi.org/10.5038/2157-7129.2.1.4 Available at: https://digitalcommons.usf.edu/abo/vol2/iss1/5

This Scholarship is brought to you for free and open access by Digital Commons @ University of South Florida. It has been accepted for inclusion in ABO: Interactive Journal for Women in the Arts, 1640-1830 by an authorized administrator of Digital Commons @ University of South Florida. For more information, please contact digitalcommons@usf.edu. 


\section{'A Strange Sympathy': The Rhetoric of Emotion in The History of the Nun; or, The}

Fair Vow-Breaker

\section{Keywords}

Aphra Behn, emotion, History of the Nun, reader response, rhetoric

\section{Creative Commons License}

(c) $($ i) $\Theta$

This work is licensed under a Creative Commons Attribution-No Derivative Works 3.0 License. 
Aphra Behn's 1689 novella, The History of the Nun; or, The Fair Vow-Breaker, presents an opportunity to explore the portrayal of suffering and victimhood in an unlikely place: the figure of a double murderer. The titular nun, Isabella de Vallery, succumbs to earthly love and elopes, a decision that propels her to hardship, unintentional bigamy, and spousal homicide. The little critical attention the text has received has tended to focus on the novel's use of its criminal protagonist as an instrument of progressive social critique, opening exciting paths of inquiry, such as what it implies for a canny murderess to represent British subjects and the monarchal crises or to stand in for women denied access to desire or legal power. ${ }^{2}$ Although Behn deluges the reader with Isabella's displays of wretchedness, critical work on the novel tends to elide Isabella's spectacular suffering or repurpose it as an instrument of a political or moral message. Perhaps because of a feminist tendency to recoil from readings that deprive female protagonists of strength and agency, critics tend not to view Isabella as a vulnerable emotional being.

Critics who have engaged with the notion of Isabella as a victim and a sufferer have tended quickly to dismiss the idea. Scholars who have written about Behn's Isabella have asserted that despite the volume of her tears and the volume of words devoted to those tears in the text, she remains unsympathetic. Critics throughout the twentieth century contrast Behn's Isabella with the Isabella of later versions of the tale, particularly the stage version by Thomas Southerne, 1694's The Fatal Marriage. Montague Summers, who rediscovered Behn's novella in 1915, finds Southerne's Isabella, a clear victim, much worthier of pity than Behn's Isabella, who commits reprehensible acts (260). Ann Messenger, writing in 1986, concurs with Summers, pointing to the blamelessness and pathetic soliloquizing of the play's heroine as incitements to compassion while noting the absence of these in the novella (54). Building on Messenger's argument, Jacqueline Pearson in 1993 also sees Behn's heroine as unsympathetic, but she views this deficiency as a signifier of parity, seeing the guilt of the nun as indicating complexity and agency not possible in an innocent victim (237). All of these scholars present victimhood and agency as mutually exclusive, and they do not give credence to the instances in which Behn's capable, culpable Isabella experiences herself as rendered powerless by emotion, circumstance, and fate.

By viewing Isabella solely as an evildoer, a proto-feminist agent, or a mechanism of social critique, recent readings of The History of the Nun, though useful and compelling, can replicate a dismissal the text itself performs. Just as contemporary criticism often reduces Isabella to symbols and tools, the text reduces her character to her appearance and actions. While the text includes bountiful evidence of Isabella's suffering - from her inappropriate desire, her fear for her husband's life, and even her decision to kill—it primarily presents that suffering as observed and performed rather than rendering it as felt, and at times does not depict her anguish at all. The narrative location of Isabella's moral torment in and through her body fetishizes female pain as a lascivious spectacle and withholds sympathy by framing such suffering as manufactured. Isabella's sincere suffering is obscured by a gendered aesthetics of suffering.

Ignoring Isabella's pain reduces both her complexity and depth and the rhetorical complexity and depth of the novella itself. At the heart of Behn's novella is a young woman in agony, and dismissing her suffering as fake or irrelevant diminishes her and makes readers complicit in the desire to dismiss or deny the female sufferer as other than a symbol of either fetish or falsehood. This paper argues that it is in and through her pain that Isabella metamorphoses from a voiceless, 
agonized body to a masterful performer, and that her ability to mask her pain directly affects her fate. Attention to the centrality and particularity of Isabella's suffering generates new ways of framing the text's engagement with femininity and reveals how the novel suggests suffering itself as a source of power. This essay looks closely at the rhetoric of suffering in the novella to trace the ways in which the text levies opposing visions of Isabella and to problematize the equation of female suffering and powerlessness with performative manipulation or lack of agency altogether. By uncovering the sincerity of suffering present in the text and allowing pathos and powerlessness into feminist critical discourse (in this case by granting sympathy to a murderess), readers can locate humanity in wretchedness and power in resilience.

Despite Isabella's capacity to act in her own interest, Behn depicts her as predominately agonized and menaced. While Isabella ostensibly makes the crucial decisions in the story, the language Behn uses to represent her struggles rhetorically victimizes her. Early on, the text suggests that Isabella is not an agent in her own life, but rather a victim of forces beyond her control. When she falls in love with Henault, she succumbs to "a disease, which must, she knew, either end in her death or destruction” (15). The states of mind and circumstances driving Isabella's snowballing misfortune possess her body as an invading sickness. After this assailment, Behn portrays Isabella as a passive object; she is "forced" by circumstance repeatedly: fate "would...force her hand to commit a murder upon itself” (16); she is "compelled by a mighty force, absolutely irresistible, to speak" (22); and is "forced to permit that to conquer her" (24). This invisible power commandeers her, wresting control of her own body away from her. Some unseen hand shoves her toward her destiny. The word "force" acts as both a godlike authority that oppresses her and as a dominating energy that drives her, conveying her sense that her own decisions originate from a point outside herself.

Behn draws attention to Isabella's pitiful and unsuccessful attempts to break the grasp of her dark fate. In the grips of her sinful love for Henault, while searching desperately for thoughts to bring her comfort, "she endeavors to fly, all frighted with horror; but, alas! whither would she fly but to a life more full of horror?" (15). And later, after she has killed Henault to avoid discovery as an unintentional bigamist, she again tries to flee from her shame. Villenoys arrives home after the murder to find Isabella "flying from him... with all the speed she could" (37). The urge to escape from the hopeless plot constraining her fills Isabella, but she finds that attempting escape is useless. Her struggles, both metaphorical and physical, prove fruitless. Behn portrays Isabella as a vulnerable body caught in the trap of her life. If only a victim merits sympathy for her suffering, as the previously mentioned critics posit, then Behn's Isabella deserves pity for being constrained and brutalized.

A reader's sympathetic response to the character of Isabella need not be contingent only on her powerlessness. Adam Smith elaborates on the mechanism of sympathy in ways that resonate with current neurobiological theories and illuminates the openings that Behn creates for readers to respond to Isabella's suffering. In contrast with David Hume's idea of sympathy as spectatorial, Smith writes that the only way to sympathize is mentally to place oneself in the person of the sufferer and imagine what one would feel. Imaginatively entering into the body of the sufferer enables understanding of that person's pain, much as scientists now describe the operation of the insula and mirror neurons in empathetic re-creation of pain. 
The theory that sympathy has a physical component is significant because historically, brutality toward subjected bodies has been justified by the claim that those bodies do not register sensation and emotion in the same way as the bodies that subject them. For example, the body of a slave was thought to be so fundamentally unlike his master's body that what would be painful and shameful to the master would barely affect the slave. ${ }^{3}$ This way of thinking allows the continuance of cruelty. By identifying instead-by inhabiting the body of another-the sympathizer experiences the sufferer as fully human.

Isabella's drama exists within a frame that encourages identification. Kirsten T. Saxton argues that The History of the Nun forges a chain of female author, female narrator, female protagonist, and female reader, involving all in a transgressive discourse on morality and desire for women's social advancement (33). The logical product of this chain would be a reader's investment in Isabella's dilemmas. Particularly in the introductory narration, Behn draws attention to the injustices women of the time held in common, and rebellion against these injustices unites author, narrator, protagonist, and reader. The reader may not condone Isabella's ultimate violent response to her feminine ensnarement, but she has a stake in the outcome of the scenario, which mirrors the social traps a woman of Behn's era had to navigate. This incitement to connect affects even a modern female reader, who may see echoes of present double standards in Behn's text. Structurally, the novella invites the identification that Smith describes as a necessary precursor to sympathy.

Behn compounds the sympathetic frame of the novella with moments that locate the reader in Isabella's body, delineating her suffering through her sensations. Fiction creates the rare possibility of placing the reader in the body of a character. Narration that travels into the body of a character and describes experiences in terms of physical sensations facilitates Smith's emotional synthesis. When Isabella's friend Katteriena tells Isabella that her beloved Henault no longer loves her, it is "a dagger to the heart of Isabella” (21). The metaphor, in addition to foreshadowing the story's violent end, serves to make tangible the effects of Isabella's anguish. The sharp stab of physical pain drives home the agony that pierces Isabella suddenly and with devastating effect. Later, Isabella feels "the pangs of killing grief," and the reader again experiences the personal, physical language of suffering (40). Portrayals that fixate on Isabella's appearance while in pain may overshadow these moments that viscerally convey her misery, but here Behn allows access to Isabella's inner self and shows that beneath the surface, she suffers intensely.

Behn figures Isabella's emotional pain as the ultimate agony: death itself. After realizing her bigamous predicament, Isabella feels unable to cope with her horror. Behn writes that she "had scarce life" to speak, and later, she "dies to think...that he should know she had been so lightly in love with him to marry again; and she dies to think that Villenoys must see her again in the arms of Henault” (35). Just as previously her emotional pain formed a dagger in her heart, in this quote Isabella figuratively loses her life in her distress. Her shame is truly mortification. In a fictional trope that later finds iconic expression in Samuel Richardson's Clarissa, a woman whose virtue has been stained can redeem herself only by dying of shame; her sensibility conveys her worth, though at the expense of her life. When Isabella "dies," she figuratively becomes a violated martyr. 
Though the text asserts Isabella's sincere mortal anguish, it also directs the reader to look askance at it. At the most crucial emotional moment in the novella, when the husband Isabella thought dead has returned and is on the verge of discovering that she has remarried, making her a bigamist and endangering her life, the narrator hints at hellish torment but declines to elaborate on the meditations that precede Isabella's murderous intention. Behn writes, "after a thousand convulsions, even worse than death itself, she resolved upon the murder of Henault . ..” (37). Her agonies attenuate to what can be contained in a dependent clause. The independent clause takes precedence as her ultimate, fatal decision, and for the sake of the plot, it is the most important element contained in the sentence. The sentence directs the reader to pass over Isabella's struggles with her conscience as a minor prelude to her cruel and logical choice. Isabella's suffering is as easily diminished as this nod to it is easily subsumed by her resolution, but the words that describe her suffering, taken out of the parenthetical of the sentence, depict pain that nearly eclipses the act of murder. Isabella here experiences something more awful than death, and she experiences it thousands of times over.

The horrors Isabella endures are amplified by the hyperbole of their phrasing and then subordinated by their presentation. Behn's use of hyperbole here and elsewhere can be seen as a hypervaluation of Isabella's experience. By portraying Isabella's pain as the ultimate sacrifice, she underscores the enormity of Isabella's emotion. This is significant in that a woman's subjective experience is often minimized even in plots where she features as the protagonist, and it is usually entirely negated in narratives of female criminals. Behn's metaphorical excess, if considered seriously, makes Isabella's pain impossible to ignore. Unfortunately, the hyperbolic characterization itself diminishes her pain by inflating it. Isabella's agonies occur over a matter of hours at most. The idea that she could experience thousands of distinct convulsions, each one so intense and unbearable as to be worse than death, seems unlikely. Once this overstatement casts doubt as to the real degree of Isabella's suffering, the question of whether her suffering is severe at all comes into play. Her contentious suffering is then buried within the construction of the sentence and easily dismissed as inconsequential in comparison with her intended action, which expresses none of the agonies she has suffered.

However, supporting an interpretation of Isabella's misery as actual and extreme, The History of the Nun offers abundant physical proof of her suffering. When Henault decides to go to war, "it possessed her with so entire a grief that she miscarried” (29). The text manifests her sorrow on her body, producing the tangible effect of a miscarriage. The miscarriage as a symbol has much traction. Saxton argues that it functions as a critique of Henault's character and behavior (37); Pearson considers Isabella's lack of children as an attempt at making non-maternal identities for women acceptable (239); it could also be argued that the miscarriage is just another in a series of misfortunes that serve to show God's displeasure with Isabella for breaking her clerical vow to marry Henault. For the purposes of exploring the representation of Isabella's suffering, it is more fruitful to consider the miscarriage as an extreme instance of the text manifesting Isabella's emotions on her body: her love, fear, and anguish are so all-consuming that there is no room in her body for the baby along with the grief. This grief then becomes self-perpetuating, as she must suffer the physical and mental torment of the loss of the child.

This physical proof is not necessarily of the sort that acts as a gateway to sympathy, however. While providing evidence of Isabella's suffering, it also places the reader in the position of a 
remote spectator rather than an identifier. When Isabella agonizes over her forbidden and unconquerable love, "her complexion grew . . . pale and languid; she was observed not to sleep or eat as she used to do. . . she was heard to sigh often . ..” (12). The narrator does not convey what Isabella felt, but instead comments on the changes that sorrow has wrought on her body. The narrator does not even speak with authority about these changes: the passive voice implies some anonymous observer who looks on as Isabella wastes away. Isabella's silence on the subject of her pain, the absence of narration of physical sensation, and the lack of an identifiable observer muffle Isabella's suffering. The only source of "speech" is her body, as it announces her emotional ruin by deteriorating and releasing wordless exhalations of woe. The reader resides at such a distance from physical sensations and lingual interpretations that identification would be a struggle.

Complicating sympathy for Isabella, narration that inhabits her body blurs the line between suffering and desire. In the above quote, Isabella expresses torment over her unconquerable sexual desire, succumbing to agony and lust in an often-fetishized marriage of a woman's torture with lascivious spectacle. When Isabella finds herself in love-or lust—with Henault, she battles her emotions fiercely: "she had raged and struggled with this unruly passion, 'till she was quite tired and breathless," and then she gives in to her passion, "in that soft fit had a mind to satisfy her panting heart” (16). The physicality of Isabella's inner turmoil recalls the previously discussed portrayals of her violent grapple with her horror and with her fate. Once more her troubles are embodied by language, and she wrestles with them, ultimately finding herself too weak to surmount them and ceding control of her body to a paroxysm that rattles her deeply. Yet here, the emotion she so furiously attempts to smother is pleasurable, and the language suggestive of enjoyable sensation and even orgasm.

The blending of pleasure and pain may be a trope in amatory fiction, but the unclear boundary between the two sensations confuses attempts to understand the degree to which Isabella suffers. Saxton characterizes the violent portrayal of Isabella's first encounter with desire as typical of the language widely applied to female sexuality at the time (36). Quotes such as "the more she concealed her flame, the more violently it raged" can productively be read as coded references to unslakable lust and thereby reveal a parable of the futility and even danger of rigidly enforcing female chastity (15). Yet Behn's language also veers from sexual metaphors to naked tragedy, as after Isabella tries to stifle her desire with redoubled holiness: "all this did but augment the pain, and was oil to the fire, so that she now could hope that nothing but death would put an end to her griefs and her infamy” (15). The anguish and horror Isabella experiences at her own lust is cast in the strongest terms. In her experience of pleasure, she suffers agonies that make her wish for an end to her life.

The linguistic melding of eroticism and violence recalls the way that contemporary fiction often confounded desire, horror, and feminine physical weakness. Toni Bowers points to the amatory convention of enforced complicity that Behn employs while recognizing Isabella's powerlessness against fate (66). The heroines of romances written at this time typically resist the illicit loss of their virginity, sometimes to the point of falling unconscious, yet appear to simultaneously crave that forbidden experience and enjoy the act fully. By being conveniently physically compelled, these women achieve their desire while preserving the appearance of virtuous intentions. Similarly, Isabella finds herself helpless against fate and is nonetheless 
complicit in her sin. The danger, of course, in eroticizing suffering and afflicting desire is that genuine resistance and anguish can be diluted or dismissed.

Contributing to the dilution and dismissal of Isabella's suffering, any description of sorrow at all is strangely absent from the moments in the text when one would assume her to be most distraught. In a moment of crushing despair, when Isabella receives the (mistaken) news that her husband has died on the battlefield, Behn writes, "When this news arrived, it may be easily imagined what impressions or rather ruins it made in the heart of this fair mourner" (31). The narrator prompts the reader to do the work of imagining Isabella's suffering while emphasizing her appearance at this moment of extreme distress. The only word that suggests Isabella's devastation is "ruins" - connoting ugly piles of rubble, disorder, decay, disaster, irreparability. This single strong word of anguish is couched delicately as an afterthought to the much softer "impressions." The word of unsightly trauma becomes secondary to the neutral, tactile word, covering over pain with a gentle caress and ending with the emphasis on her picturesque sadness. The ruins are blanketed in language of sensuality, mirroring how Isabella's brutal pain is masked and diminished by concerns of appearance. This kind of phrasing elides Isabella's suffering; it interposes an imaginary person between the reader and the narrator, and the reader would need to pass through both the imagined sympathetic person and the neglectful narrator to understand the character herself.

Image often takes precedence over the true suffering that lies beneath. Both Isabella's sorrow and her femininity are brought into focus in the aesthetics of suffering, and they are both figured as frail and appealing. Behn writes, "she spoke with a fainting tone, and the tears fell anew from her fair soft eyes” (23). She speaks weakly, "with a fainting tone," which is notable because her distress often deprives her of her voice entirely. Here, she can speak, but only weakly and with great difficulty. Her tone, her very voice, the vehicle through which she might articulate her experience with authority, is embodied as a stereotypical swooning woman. The second clause of this sentence does not even allow her the agency of producing her own tears: the tears "fell" of their own accord. The text once again presents Isabella as a lovely body that manifests signs of suffering. The reader witnesses the physical manifestations of her suffering, and it arouses the senses to pleasing sensations: a soft voice and lovely eyes. The pain is lost in its beautified representation.

The text's occupation with Isabella's attractive suffering extends to how other characters react to her in the midst of her grief. When Villenoys beholds Isabella for the first time after years of hardship, most recently the news that her husband has died at war, "he found her in her mourning a thousand times more fair...but the awful sadness and soft languishment of her eyes hindered him from the presumption of speaking of his passion to her” (32). Villenoys responds to her misfortune as alluring first, without any evidence of sympathy for her obvious pain. Yet even as he responds to her desirable suppleness more than her sadness, he experiences her emotions as powerful and even silencing.

The physical expression of suffering seems to preclude Isabella's own ability to express her pain in words, which diminishes her subjectivity. Throughout the novella, her distress expresses itself while language repeatedly fails her. In the first flush of her agonizing love, “'twas rather a soft silent grief that eased itself by sighing” (13). Later, when she cannot vocally communicate her 
hellish pain and longing to Henault, she communicates with "eyes that told him her heart was burning and dying for him” (22). At the culmination of Isabella's misery, when she has murdered one husband and been found running through the house, crazed with misery by the other: "she fell into a swoon," and when he asks her what is wrong, "She only fixed a ghastly look upon him, and said she was not well" and then "fell a weeping in a most violent manner" (38). Almost the only way Isabella expresses her torment is through her body's observable signs. Her appearance in agony, when it is not soft and lovely, suggests the carnage of the emotional netherworld she inhabits, but it does not invite the reader to sympathetically engage in her pain. It is as a body that the reader sees her: a weak body, a body writhing in torment, but not a comprehensible body.

In contrast, Henault, though seeming to suffer far less than Isabella, possesses the power to express his pain in words. After Isabella has reproached him for hesitating to elope with her, he asks her, "how industrious is your cruelty to find out new torments for an heart already pressed down with the severities of love?” (25). He expresses his pain in language that allows a reader to imagine the sensation of his suffering, and rather than impotently enduring it, he accuses the person he sees as inflicting it. Isabella does not articulate her pain in this manner; she can express herself rationally in words, but her emotions can only be spoken by her body. Henault rages against what he perceives as the source of his troubles and phrases his pain in effective terms. Isabella blanches, faints, weeps, sighs, falls ill, wastes away, miscarries, and never voices a complaint.

However, there are instances when Henault shows pain in a way similar to Isabella's. Between verbal expressions of his anguish, "tears glided down his cheeks" (17), and shortly after, "tears gushed from his eyes, and he was able only a good while to sigh" (19). In these moments, Henault is objectified and silenced by the form his suffering takes, though the word "gushed" implies more of an unnatural, abject state than Isabella ever experiences in her sorrow. As Pearson notes, Henault is "feminized" in his descriptions and by his circumstances, which may explain why the text sometimes mires him in the physicality and passivity in which Isabella repeatedly drowns (247).

The appreciation of women (or feminized men) as primarily aesthetic objects (the "male gaze") has been argued to diminish women as thinking, feeling, acting beings. Similarly, the aestheticizing of women's suffering prompts readers to respond to that suffering visually, not viscerally. Because narration traditionally approaches female characters in the extremes of their pain as beautiful, it deflects empathy and perverts sympathy by marrying it to erotic stimulation. Laura Hinton has thoroughly discussed the operation of this "perverse gaze of sympathy," most pertinently in relation to Clarissa, yet her readings do not allow for an escape from the traps of voyeurism and subjugation.

Isabella gains an amount of control in her own representation by manipulating perceptions of her emotions. Revealingly, when Isabella attempts to convey her suffering to Henault, she herself participates in figuring her pain as exterior by expressing it as image, not as sensation. She asserts that she will suffer her love for him without requiting or being able to conquer it if he won't marry her: "you shall see how pleased I will be to languish here; but as you see me decay (for surely so I shall), do not triumph o’er my languid looks and laugh at my pale and meager 
face... love your slave that dies and will be daily and visibly dying ...” (23). Her announced intention of enduring tragedy mutely communicates her implied criticism of his behavior in an acceptably feminine manner. She casts herself as a martyr, and indeed, the fortitude with which she endures the many emotional deaths she suffers could make her a martyr several times over.

Isabella emphasizes the physical evidence of her suffering body in the same way the narrative does, while projecting the extremity of her pain in the image of death. The passive, unprotesting wasting away that Isabella imagines here is complicated by the fact that she produces and controls this image of herself. The fact that, in this rare instance of her asserting her emotions, she chooses to project the image of socially appropriate feminine suffering prompts a consideration of what is at stake in Isabella's manipulation of her image as a sufferer.

Isabella's first successful act of deception initiates her into a craft that Behn represents as uniquely feminine. When Isabella decides to lie and say she's conquered her passion for Henault, "she resolved to see him and to dissemble with Katteriena so far as to make her believe she had subdued that passion she was really ashamed to own; she now with her woman's skill begins to practice an art she never before understood and has recourse to cunning and resolves to seem to reassume her former repose," and she "composed her face to more cheerfulness" (17). Isabella wishes to smother her shameful passion, and in response to her inability to quell it, she invents a persona who can retain the spotless virtue of which she had previously been mistress. The presentation of the skill of deception as a feminine art could be seen as an acknowledgment that the only way for women to live up to the standards set for them is by concealing their true acts and feelings. The language here supports an uncritical interpretation, as Isabella engages in womanly deception as an "art" and "composes" her face into an image of placidity. By lying, she practices a craft akin to writing music or painting, creating a reality and becoming more dexterous and powerful in the process.

While Isabella wields power in the management of others' perceptions of her emotions, it can be argued that this very seizure of control dooms her. Isabella's decline into evildoing is so skillfully portrayed that it is difficult to pinpoint any of her choices before murder as particularly bad, though one could also read every choice she makes as leading toward the snare that ends in murder. Considering the title of the novella, it seems beyond debate to locate Isabella's downfall in her broken clerical vow or her broken marriage vow, and ample evidence exists to blame vowbreaking for her misfortune. Yet, the root of her troubles also appears to lie in the concealment of her emotions, though this ability is what enables her to survive as long as she does while making the choices she feels compelled to make.

In order fully to appreciate the power Isabella wields in the manipulation of her feminine affect, it is necessary to consider the danger in which her emotion would place her. The perceptions of others are intimately tied to her anxieties: she "considers where she shall show her face" after eloping (24) and worried that the "town...will look on her as an adulteress" if they discover Henault lives (35). In order to maintain a social and economic position that is intrinsic to her livelihood, Isabella manipulates appearances by any means necessary. Even so, it would be a mistake to see her as a performer who lacks substance. The very depth of her emotions necessitates the construction of an unbreakable mask, one that will conceal her utter despair and thus preserve her life. 
The disintegration of Isabella's ability to separate her pain from her appearance leads to her death. When people console her over the news of Henault's fate at war, her longstanding ability to conceal her suffering slips: "however [her soul] was oppressed within by Henault's absence, she bore it off with a modest cheerfulness; but now she found that fortitude and virtue failed her when she was assured he was no more" (31). This quote reveals the symbiosis of Isabella's deception and her reputation. When she cannot lie to conceal her sorrow, it is her virtue that fails her. Her virtue and her ability to construct falsities have been inextricably entangled, and when one begins to slip, so does the other. Finally, her desire or ability to deceive crumbles to the point where, when confronted with the murder of her two husbands, she responds with absolute honesty and "without any disorder delivered herself in the hands of justice" (42). This may signify her desire (or fiction's demand) for a moralistic end to her life. It may also be the inevitable endpoint of her gradual inability to keep up appearances in the face of unbearable emotional burdens.

In The History of the Nun, the production and concealment of emotion are more central to the definition of Isabella's character than is her actual experience of emotion. Though the narrator illuminates her feelings at times, the text focuses overwhelmingly on her physicality, often preventing identification and sympathy. Isabella's capacity to manipulate her expression of emotion acts both as an incitement to sin and as a lifeline. Concealment of emotion allows her to gain some amount of control over her bleak situation and functions as an extension of her reputation, which allows her to achieve some version of a tolerable life. She seems to transcend the reality of the circumscribed body she inhabits with her ability to counterfeit and control her emotions.

The perception of Isabella as unsympathetic can be bolstered by the wording of the text, which fixates on appearances to the point that Isabella becomes flattened in her most pitiable moments. The pain she evidently experiences can therefore be diminished and dismissed. Much in the way the text conceives of her as a feminine body, criticism has tended to focus on what Isabella does and what she represents, rather than the wellspring of sorrow and fear that drives her.

Paralleling the fracture of Isabella's serene persona under the pressure of her many sorrows, the mask of placidity surrounding the representations of Isabella's emotions also shows cracks when examined closely. The reader can see glimpses of Isabella's real, felt pain, and by focusing closely on those glimpses, make her more than a performer of appearances and actions. Viewing Isabella as a sufferer and as a victim does not have to reduce her to an object or deprive her of agency. A full exploration of the complexities of the representation of Isabella's pain and powerlessness can grant her the personhood she otherwise lacks when one responds to certain cues in the text and does not attempt identification. There is great value in considering Isabella as a vow-breaker and a murderer, but there is equally great value in considering her as an emotional being. Isabella feels intensely; she navigates being trapped in seemingly hopeless situations; she confronts the blackest of inner hells, and she endures. Through her emotions, Isabella dies many times before her executioners deliver the final blow. Each time her distress eviscerates her, she rises from the dead and continues to struggle. Isabella's resilience reveals that suffering and lacking power do not have to be equated with being weak and useless and lacking agency. The 
ability to dwell in powerlessness, uncertainty, and agony can be seen as strength; recovery can be defiant; victims can be aggressors; and a murderess can be sympathetic. 


\section{Notes}

1. The title of this essay is taken from the point in the novella when Isabella tells her first lie to conceal her anguished love from her friend. Her lover, Henault, independently reaches the same decision, to pretend that he has overcome his doomed passion. Behn writes, "as if he had known what passed in Isabella's heart, he, by a strange sympathy, took the same measures to deceive Katteriena” (20). Of relevance to this paper is the manipulation of affect and the indirect route Henault traverses to reach identification with Isabella. The fact that Isabella appears to infect Henault with her deception, in contradiction to the narrator's assertion that men originate sin, deserves further examination.

2. See Bowers, Messenger, Pearson, Saxton, and Thompson.

3. See Janet Schaw's infamous observations on slavery in the eighteenth century, though this assertion was prevalent in many pro-slavery discourses. 
Works Cited

Behn, Aphra. The History of the Nun; or, the Fair Vow-Breaker. Popular Fiction by Women, 1660-1730: An Anthology. Ed. Paula R. Backscheider and John J. Richetti. New York: Oxford UP, 1996. 1-42. Print.

Bowers, Toni O’Shaughnessy. "Sex, Lies, and Invisibility: Amatory Fiction from the Restoration to Mid-Century.” The Columbia History of the British Novel. Ed. John J. Richetti. New York: Columbia UP, 1994. 50-72. Print.

Hinton, Laura. The Perverse Gaze of Sympathy: Sadomasochistic Sentiments from Clarissa to Rescue 911. Albany: State U of New York P, 1999. Print.

Messenger, Ann. His and Hers: Essays in Restoration and Eighteenth-Century Literature. Lexington: UP of Kentucky, 1986. Print.

Pearson, Jacqueline “The History of The History of the Nun.” Rereading Aphra Behn: History, Theory, and Criticism. Ed. Heidi Hutner. Charlottesville: U of Virginia P, 1993. 234-52. Print.

Saxton, Kirsten T. Narratives of Women and Murder in England, 1680-1760: Deadly Plots. Burlington: Ashgate, 2009. Print.

Schaw, Janet. Journal of a Lady of Quality; Being a Narrative of the Journey from Scotland to the West Indies, North Carolina, and Portugal, in the Years 1774 to 1776. New Haven: Yale U P, 1923. Print.

Smith, Adam. The Theory of Moral Sentiments. Part I, Chap. I: “Of Sympathy.” 1759. Web. 1 Oct. 2011. http://www.marxists.org/reference/archive/smithadam/works/moral/part01/part1a.htm.

Summers, Montague, ed. The Works of Aphra Behn. Vol. 5. 1915. New York: Blom, 1967. Print.

Thompson, Helen. Ingenuous Subjection: Compliance and Power in the Eighteenth-Century Domestic Novel. Philadelphia: U of Pennsylvania P, 2005. Print. 